\title{
Studies on Spray Characteristics of Kerosene Alternative Fuels for Special Vehicle Diesel Engines
}

\author{
Zhixin Sun ${ }^{1, a}$, Xinyong Qiao ${ }^{1, b}$, Ruoting $\mathrm{Li}^{1, \mathrm{c}}$ and Ning Ma ${ }^{1, \mathrm{~d}}$ \\ ${ }^{1}$ Department of Mechanical Engineering, Academy of Armored Force Engineering, \\ Beijing, China, 100072 \\ Corresponding author: ${ }^{\mathrm{a}}$ sunzhi-li@163.com, ${ }^{\mathrm{b}} \mathrm{qxyaafe@sina.com},{ }^{\mathrm{C}}$ liruoting1987@126.com, \\ dm18610465261@163.com
}

Keywords: special vehicle; diesel engine; kerosene; emergency alternative fuels; spray

Abstract. Experimental studies to compare spray characteristics of kerosene fuels and diesel fuel were performed in a constant-volume vessel. Three kinds of fuels such as -10\# diesel, aviation kerosene and lamp kerosene were tested. The spray characteristics were studied by use of the shadowgraph method. The spray cone angle and penetration were observed. In general, the spray cone angles of the kerosene fuels are slightly larger than that of diesel fuel. In the initial range of the spray, about $0 \sim 0.5 \mathrm{~ms}$, the spray cone angles of aviation kerosene and lamp kerosene are bigger than diesel fuel at the same time, by $11.2 \%$ and $10.3 \%$. The spray penetration of the two kerosene fuels are nearly the same with the difference less than 3\%. Meanwhile the penetration of diesel fuel is significantly about $18.3 \%$ and $17.1 \%$ longer than kerosene fuels.

\section{Introduction}

Special vehicles are used to carry out so many important works, such as military actions, engineering rescues and fire-fighting rescues. Considering the particularities of their working circumstances, they wouldn't accomplish their tasks for fuel shortage if their fuel supply chain, which consists of the fuel depots, fuel supply stations and pipelines is cut off. Therefore, how could we solve the fuel supply problem while the special vehicles have urgent tasks to accomplish fuel the special vehicle engines with alternative fuel that could be found easily without engine structure modification is a realistic measure. Kerosene is one of the best options.

Kerosene a middle distillate of petroleum based fuel. Generally, it can be classified as two types by purpose of use: aviation kerosene and lamp kerosene. From 1990s, many abroad researchers have carried out studies on the performances and emissions on engines fueled with kerosene [1-5]. But no reports was retrieved about the special vehicle engines fueled with kerosene at home.

In the working process of diesel engine fueled with alternative fuels, the changes of fuel physical and chemical properties lead to the changes of fuel spraying characteristics, and directly affect the combustion efficiency, power output and economy of diesel engine [6]. Therefore, experimental studies on the kerosene fuel spray characteristics in constant volume vessel were carried on in this paper. The results provide the experimental basis for the application of kerosene as special vehicles alternative fuels when emergency.

\section{Test Equipment and Scheme}

Test Equipment. This fuel spraying test was carried out on a constant volume vessel bench which is designed to study fuel spraying. The test system is composed of a constant volume vessel, a common rail system, a high-speed photography system, a data acquisition system and a control system, as shown in figure 1. 


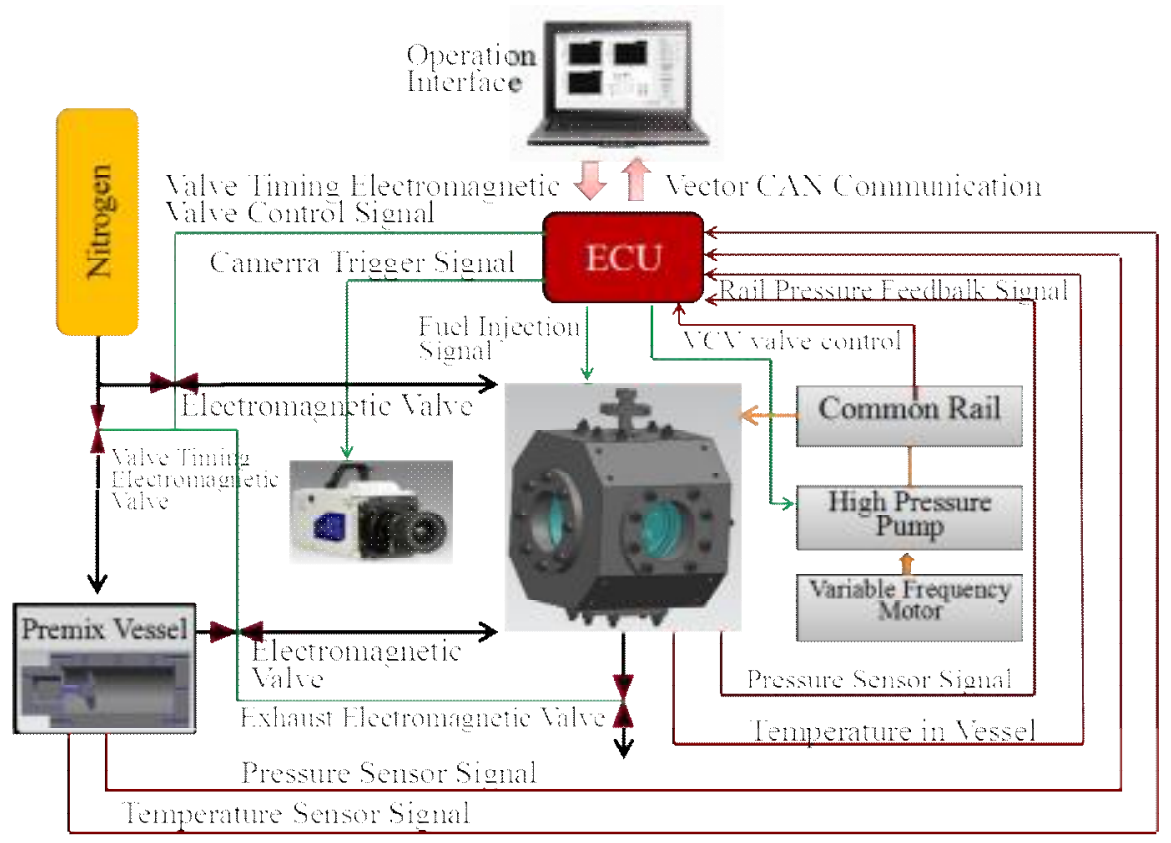

Figure 1 Test system for fuel spray

Tested Fuels. Three kinds of fuels were tested: $-10^{\#}$ diesel, aviation kerosene and lamp kerosene. The main physical and chemical properties are shown in Table 1.

Table 1 Physical and chemical properties of the tested fuels

\begin{tabular}{|l|l|l|l|}
\hline Item & Diesel & $\begin{array}{l}\text { Aviation } \\
\text { kerosene }\end{array}$ & $\begin{array}{l}\text { Lamp } \\
\text { kerosene }\end{array}$ \\
\hline Density $\left(20^{\circ} \mathrm{C}\right) /\left(\mathrm{g} \bullet \mathrm{cm}^{-3}\right)$ & 834.0 & 785.4 & 794.0 \\
\hline Viscosity $\left(20^{\circ} \mathrm{C}\right) /(\mathrm{mm} 2 \bullet \mathrm{s}-1)$ & 4.611 & 1.506 & 1.826 \\
\hline Flash point $/{ }^{\circ} \mathrm{C}$ & 79.5 & 53.5 & 50.5 \\
\hline $10 \%$ recovery temperature $/{ }^{\circ} \mathrm{C}$ & 231.0 & 171.0 & 181.4 \\
\hline $50 \%$ recovery temperature $/{ }^{\circ} \mathrm{C}$ & 270.5 & 188.0 & 205.9 \\
\hline $90 \%$ recovery temperature $/{ }^{\circ} \mathrm{C}$ & 320.0 & 214.5 & 236.0 \\
\hline Cetane number & 50.8 & 53.5 & 49.1 \\
\hline Lower heat value $/(\mathrm{MJ} \cdot \mathrm{kg}-1)$ & 43.18 & 42.90 & 41.00 \\
\hline
\end{tabular}

As shown in table 1: compared with diesel fuel, aviation kerosene or lamp kerosene has significantly lower viscosity and density, better fluidity. But their flash point and distillation temperature are lower, which leads to worse safety. The cetane number of aviation kerosene is higher than that of diesel oil, while lamp kerosene is slightly lower. And the Lower Calorific Value of these two kinds of kerosene fuel are lower than that of diesel fuel.

Test scheme. The spray characteristics of three kinds of fuels were studied by means of the shadowgraph. The whole spray process was recorded. A single hole injector was used, and diameter of the hole is $0.28 \mathrm{~mm}$. Each test was repeated 3 times in order to reduce the error. The test condition is shown in Table 2 .

Table 2 Test condition of fuel spray

\begin{tabular}{|c|c|}
\hline Environment temperature/K & 298 \\
\hline Injection pressure/MPa & 30 \\
\hline Injection pulse width/ms & 3 \\
\hline Background pressure/MPa & 1.0 \\
\hline $\begin{array}{c}\text { High speed camera photographic } \\
\text { speed/ ( frame } \text { s }^{-1} \text { ) }\end{array}$ & 50000 \\
\hline Resolution/pixel & $178 \times 446$ \\
\hline Exposure time/ $\mu \mathrm{s}$ & 1.1 \\
\hline
\end{tabular}




\section{Test Results and Analysis}

Analysis of Spray Characteristics. Figure 2 shows the development of diesel and kerosene fuels' spray, from the beginning of injection to $1.68 \mathrm{~ms}$ after injection.

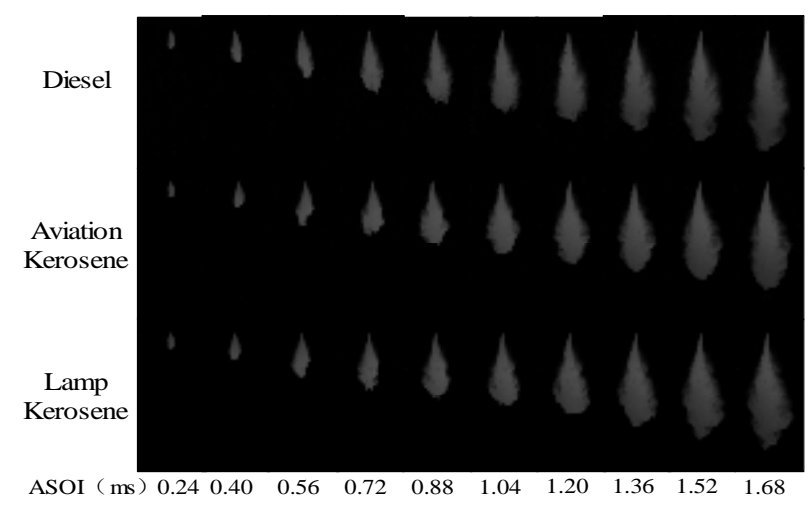

Figure 2 Spray shapes of different fuels

It is shown that the spray shapes of the three kinds of fuel have the same regularity in the developing process: the spray appeared an umbrella shape; With the development of the spray, air in the chamber is entrained into the interior of the fuel spray, mixed with the broken fuel droplets; Compared with the kerosene fuel, the spray of the diesel fuel is narrower in the front part; its spray develops faster and impinged the wall of the cylinder earlier.

Figure 3 shows the variations of different fuels' spray cone angle developed with time. In general, the spray cone angles of the two kinds of kerosene fuels are slightly larger than that of diesel fuel. In the initial range of the spray, about $0 \sim 0.5 \mathrm{~ms}$, the spray cone angles of aviation kerosene and lamp kerosene are $11.2 \%$ and $10.3 \%$ more than that of diesel fuel at the same time. As time passed, the spray cone angle of the lamp kerosene is nearly the same as that of the diesel fuel. The difference is less than $2 \%$. And the spray cone angle of aviation kerosene is $4.8 \%$ bigger than that of diesel fuel.

Figure 4 shows the variations of different fuels' spray penetration with time. It can be seen that the spray penetration curves of the two kerosene fuels are nearly same. The difference is less than $3 \%$. Meanwhile the spray penetration of diesel is significantly longer. Compared with aviation kerosene and lamp kerosene, the differences are about up to18.3\% and $17.1 \%$.

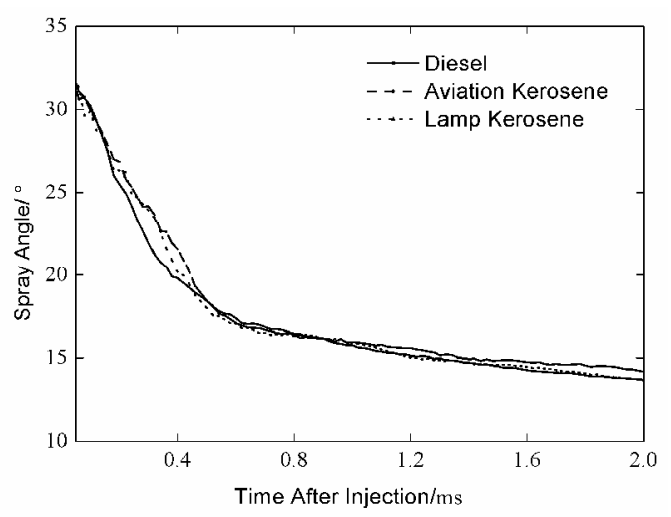

Figure 3 Comparison of spray cone angle of different fuels 


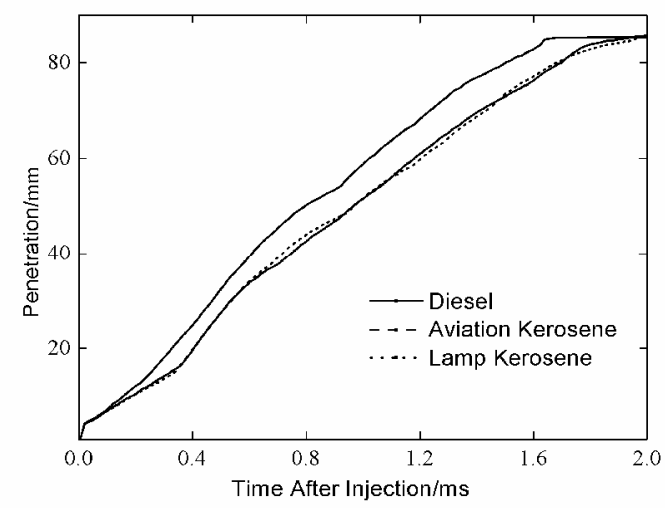

Figure 4 Comparison of spray penetration of different fuels

This is due to the fact that under the same injection pressure and background pressure the spray cone angles and penetration distances are closely related to the physical properties of the fuel. For kerosene fuel, its viscosity and density are relative less than those of diesel fuel, so the quality and momentum are smaller. During the crushing process the viscous force and inertia force of the fuel spray are smaller too. The droplets are more easily broken. This leads to larger spray cone angle and shorter penetration distance. The difference of the two kerosene fuels' physical properties is small, and the spray cone angle and penetration are general the same.

\section{Conclusions}

The viscosity and density of kerosene fuel is lower than that of diesel fuel, and the fuel droplet is easier to break in the spray process, which leads to the increase of spray cone angle and the decrease of the penetration distance.

\section{Acknowledgements}

This work was financially supported by Academy of Armored Force Engineering (2014YY02).

\section{References}

[1] Andrews G E, Abdelhalim D M, Williams P T. Characterization of diesel particulate emission of two IDI diesel engines using diesel and kerosene fuels SAE Paper 961231, (1996).

[2] Bergstrand P. Effects on combustion by using kerosene or MK1 diesel. SAE Paper 2007-01-0002, (2007).

[3] Cracknell R F, Rickeard D J. Advanced combustion for low emissions and high efficiency part 2: impact of fuel properties on HCCI combustion. SAE Paper 2008-01-2404, (2008).

[4] Rose K D, Cracknell R F, Rickeard D J, et al. Impact of fuel properties on advanced combustion performance in a diesel bench engine and demonstrator vehicle. SAE Paper 2010-01-0334, (2010).

[5] Pischinger S, Rajamani V K, Jeihouni Y. Impact of fuel properties on the performance of a direct injection diesel engine under part homogeneous operating conditions. SAE Paper 2011-01-1358, (2011).

[6] Emekwuru N. Numerical characterization of two alternative-to-diesel fuels using a moments spray model.SAE Paper 2014-01-1422, (2014). 